\title{
Gender Influences on Managerial Style and Conflict Resolution Effectiveness in Work Organisations in South-Western, Nigeria
}

\author{
A. Oluseyi Shadare, $\mathrm{PhD}$ \\ Department of Industrial Relations and Personnel \\ Management, Faculty of Business Administration, University of Lagos, Nigeria \\ Tel:+23-480-3304-9507Ｅ-mail: seyidare2001@ yahoo.co.uk \\ O. Christopher Chidi \\ Department of Industrial Relations and Personnel \\ Management, Faculty of Business Administration, University of Lagos, Nigeria \\ Tel: +23-480-2303-4213 E-mail: krischidi2002@yahoo.com \\ Oluwakemi Ayodeji Owoyemi, $\mathrm{PhD}$ (Corresponding Author) \\ Department of Industrial Relations and Personnel \\ Management, Faculty of Business Administration, University of Lagos, Nigeria \\ Tel: +23-480-5659-5701 E-mail:oluwakemi.owoyemi@yahoo.com
}

Received: November 9, $2010 \quad$ Accepted: December 30, $2010 \quad$ doi:10.5430/ijba.v2n1p54

\begin{abstract}
This study investigated the influences of gender on managerial style and conflict resolution effectiveness in work organisations in South-Western Nigeria. The findings of the study revealed that a significant relationship exists between managerial style and conflict resolution effectiveness $(\mathrm{r}=0.356 ; \mathrm{P}<0.05)$. I $\mathrm{t}$ was also found that there was no significant difference between male and female managers' conflict management style ( $\mathrm{t}(209)=17.56$; P > 0.05).It was found that a significant difference exists between female and male managers' conflict resolution effectiveness ( $\mathrm{t}(209)=$ 5.66; $\mathrm{P}<0.05$ ). Based on the findings of the study, the authors recommended that democratic management style should be encouraged as conflict resolution strategy in order to guarantee effective management of industrial conflict and sustainable peace and harmony. Thus, the participatory management style should be employed during collective bargaining process in order to foster effective management of conflict in work organisations.
\end{abstract}

Keywords: Gender, Managerial Styles, Conflict Resolution Effectiveness, Work organizations

\section{Introduction}

Gender as a concept is traceable to the 1976 University of Sussex workshop on the subordination of women (Onyeonoru, 2005); where a consensus emerged that unlike sex, which is biologically determined; women's subordination is socially constructed. Hence, while sex refers to the biological differentiation between males and females in terms of their reproductive functions, gender refers to the differentiation between the roles of men and women as socially constructed by society through socialization (Onyeonoru, 2005).Thus, while sex is biological and fixed, gender is varied in space and time and is culturally determined. Conflict resolution as a process of fostering industrial peace and harmony has in the recent times become the focus of human resource management practitioners. Researchers have embarked on investigating the differences between male and female managers concerning the preferred management style adopted for effective conflict resolution. Some researchers do not agree to the fact that gender and experience significantly have an impact on the choice of conflict resolution management style (Korabic, Baril \& Watson, 1993; Cole \&Streeter, 2003). These authors found that female managers do not differ from male managers in preferred conflict management style; but they do differ from their conflict resolution effectiveness. Leah (2005) reported that gender does not have as much influence as the experience of the managers in conflict resolution and managerial effectiveness in work places. Other 
researchers have found that multiple variables such as gender have some correlation to conflict resolution effectiveness. Of great interest is the interaction of heterogeneous (opposite sex) and homogeneous (same sex) dyads in managing subordinate conflicts (Monroe, Disalvo, Lewis \& Berzi, 1991; Akintayo, 2006). The authors investigated the effect of gender on conflict management style of supervisors in relations to difficult subordinates and reported that the supervisors' perceived sex of the difficult subordinates had the greatest effect on conflict resolution style. They also found that male subordinates used relational leverage (confrontation) more often with a female supervisor and female subordinates used avoidance more often with male supervisors. However, the researchers also noted that in same sex supervisor - subordinate dyads, these differences dramatically lessened. Specifically, the objectives of the study are to:

- $\quad$ identify the management style adopted by managers in work organizations in South-Western Nigeria.

- determine the relationship between management style and conflict resolution effectiveness.

- determine the variation in the conflict management style adopted by female and male managers

- $\quad$ ascertain the relationship between gender and conflict resolution effectiveness.

- find out the difference in conflict resolution effectiveness of experienced and less experienced managers.

Proffer plausible solutions and make recommendations towards effective conflict resolution in work organizations in Nigeria.

\section{Literature Review}

The literature reviewed in this study focused on conflict management style and effectiveness with moderating effect of gender and working experience. Carington and Charles (2001) observed that both male and female subordinates were more likely to pursue their interests in a conflict with a female supervisor and less likely to use confrontation with a male supervisor. The finding implies that managers of both genders do not possess innate conflict resolution style but that the interaction with male or female subordinate affects preferred style. Considering the conflict management style, researchers have indicated that female supervisors tend to use interpersonal, compromising, collaborative, accommodating, integrating, co-operative, avoiding, pro-social and communicative methods. In contrast, there is evidence that male managers tend to use more aggressive competitive, confronting, assertive, pro-task and coercive strategies more often and faster than female managers (Gibbs \& Lach, 1994; Lay, 1994; Sorenson \&Hawkins, 1995; Conrad, 1991; Akintayo, 2004; Ajaja, 2004; Adeyemo, 2005). Babajide (2000) noted that authoritarian style is prevalent among female managers and a democratic style is manifested by male managers.

Omole (2004), Sorenson and Hawkins (1995) reported that male managers assumed competitive conflict resolution strategy more than female managers; and female managers assumed compromising conflict resolution strategy more often in conflict than their male counterparts. Meanwhile, Duane (1999) observed that the less experienced male managers were found to be less likely to avoid conflict situations while experienced male managers were more likely to accommodate requests than female managers. The study was based on small sample management officials, which had more males (35) than females (7). Also, the study did not have consideration for management style and environmental favourableness.

In the same vein, researchers reported that male managers preferred power and authority while female managers used communication before resorting to using power (coercion). Also, female supervisors were found to use coercion less than male supervisor and often after other resolution styles do not yield desired results (Mulac, Siebold, \& Farris, 2000; Lamude \& Torres, 2000). This implies that female supervisors tend to ultimately use coercion if necessary. The authors reported further that subordinates see coercive - based technique as negative while the rewarding, referent and expert-based techniques were seen as positive by the subordinates. Meanwhile, the authors admit that their sample was non-random which may limit the level of generalisation of the findings. Reflecting on conflict management effectiveness, Faniran (2002) and Adekunle (2004) reported that experienced managers were found to be more effective in managing conflict situations than less experienced managers. The authors further reported that working experience rather than gender of the managers has been found to have significantly influenced conflict management effectiveness. Also, the authors argue that experienced male and female managers were found to be equally effective in managing conflict though their attitude may be quite different.

These studies measure perceptions of differences in conflict management styles between the genders of the managers with limited experiences. The findings of the previous studies need further empirical verification since the studies were conducted in different context and on different samples. Thus, the present study is different from the previous studies, since it is designed to investigate the contribution of management style to conflict resolution effectiveness in work organisations in South-Western Nigeria. This study investigated the relationship between gender and management style 
as well as conflict resolution effectiveness in work organisations in South-Western Nigeria. This was for the purpose of ascertaining the relative impact of gender on management style and conflict resolution effectiveness towards ensuring sustainable industrial peace and harmony in Nigeria. Onyeonoru (2005) citing Esther (1975) put forward three models which can be used to explain the scarcity of women in leadership positions. These are as follows:

- A women's place model

- A discriminatory model

- A meritocracy models

The first model (women's place model) attributes the fewness or scarcity of women in organizational leadership positions to the patriarchal nature of socialisation given women, which gave them an orientation of subordination to men, non-assertive and dependent. Hence, few women attitudinally aspire to top ranking jobs. Women who form this viewpoint are also considered poor risk takers and would avoid position where risk is a possibility. The discriminatory model, on the other hand argues that the fewness of women in leadership positions is due to the discriminatory behaviour inherent in the training and hiring of managers in which case men are preferred to women. The meritocracy model contends that the scarcity of women in leadership positions is a reflection of women's incompetence for such positions. Thus, patriarchy gives men ascendancy in inheritance, authority and decisions making in and outside the home as evidenced in Nigeria.

\subsection{Research Hypotheses}

The following null hypotheses were formulated for the study and tested at $5 \%$ level of significance:

i. There is no relationship between management style adopted by the managers and conflict resolution effectiveness.

ii. There is no difference between male and female managers' conflict management style.

iii. There is no difference between male and female managers' conflict resolution effectiveness.

iv. There is no difference between conflict resolution effectiveness of experienced and less experience managers.

\section{Method}

This study adopted the survey research design. With a view to harvesting information from respondents, a questionnaire titled 'Rahim Organizational Conflict Inventory' (ROCI) developed by Conrad (1991) was adopted for the study. The target population for the study consists of all top and middle management managers of private organisations in South-Western Nigeria. These private organisations include: Nigerian Breweries Plc., United Bank for Africa Plc, British Tobacco Company of Nigeria, MTN Telecommunication in Nigeria Plc., Nigerian Textile Industry and West African Portland Cement Plc. A total of 211 respondents, which represents eighty five percent of the total population, were selected for the study using stratified sampling and purposive sampling techniques. The respondents consist of 123 $(58.3 \%)$ male managers and $88(41.7 \%)$ female managers. The age range of the respondents was between 28-60. However, the respondents were selected using the strata of organization (manufacturing and service organisations), gender (male and female) and working experience (experienced and less experienced). The purposive sampling technique was used to select respondents, who had spent at least five years as managers in their work organisations. Also, the respondents, who had spent below 5 years as managers were ranked as less experienced while those who had spent above 10 years as managers were ranked as experienced. However, $97(46 \%)$ respondents have spent below 10 years as managers while $114(54 \%)$ respondents have spent above 10 years as managers in their organisations.

\subsection{Measures}

A set of questionnaire was utilised for data collection. The questionnaire titled 'Rahim Organisational Conflict Inventory' (ROCI) developed by Conrad (1991) was adopted for the study. The ROCI contains 35 items, which subjects response to a modified 4-point Likert response rating scale, which include; Strongly Agree (4 points), Agree (3 points), Strongly Disagree ( 2 points) and Disagree (1 point). The questionnaire consists of three sections; that is, sections A, B and C. Section A contains demographic information about the respondents, such as: name of organisation, age, sex, working experience, highest educational qualification and so on. Section B consists of items relating to management style which include: participatory (high concern for self and high concern for others); autocratic (high concern for self and low concern for others); democratic (low concern for self and high concern for others); avoiding (low concern for self and low concern for others) and compromising (intermediate levels of concern for both self and others).

Also, section $\mathrm{C}$ of the questionnaire measures conflict resolution effectiveness of male and female managers'. It also measures relationship between managerial experience and conflict resolution effectiveness. It accounts for variation in conflict management style and conflict resolution effectiveness based on gender and working experiences. Scores for 
each of the subscales are determined by averaging the 7 of the 35 total items, which address each conflict dimension. A high score represents a greater preference for the strategy indicated. With respect to the test of reliability of the research instrument, Cronbach alpha of 0.89 was obtained.

\subsection{Procedures}

The researchers with the assistance of three trained research assistants administered the questionnaire. The researchers consulted the human resource managers of the selected private organisations in South-Western Nigeria for their approval and assistance in securing the interest and attention of the respondents.

Following the permission granted by the human resource managers, the researchers explained all aspects of the questionnaire to the respondents and assured them of confidentiality of the information to be supplied. A total of 240 copies of the questionnaire were administered, the 211 copies duly completed and returned were collated and analyzed for the purpose of the study. It took the researchers complete three weeks of administering and retrieving of the questionnaires due to the geographical location of South-Western Nigeria. Data analysis was carried out with the aid of SPSS (Statistical Package for Social Sciences). The Pearson Moment Correlation and t-test statistical techniques were used to test the hypotheses at $5 \%$ level of significance.

\section{Results}

The results of the data analyzed for the study were presented on the basis of the hypotheses formulated for the study.

Ho1: There is no relationship between management style and conflict resolution effectiveness.

Table 1 reveals that a significant relationship exist between management style and conflict resolution effectiveness $(\mathrm{r}=$ 0.356; $\mathrm{P}<0.05$ ). The finding shows that collective bargaining strategy with an embodiment of participatory management style being adopted by the managers has really influenced effective management of conflict in selected work organizations in South-Western Nigeria. This implies that the managers utilisations of participatory management style tend to promote industrial peace and harmony. The result does not support or confirm hypothesis one.

Ho2: There is no difference between male and female managers' conflict management style.

Table 2 shows that there was no significant difference between male and female managers' conflict management style ( $\mathrm{t}$ $(209)=17.56 ; \mathrm{P}>0.05)$. The finding indicates that both male and female manager's equally adopted collective bargaining with implication for participatory bargaining process. The result supports or confirms hypothesis two.

Ho3: There is no difference between male and female managers' conflict resolution effectiveness.

Table 3 reveals that a significant difference exists between female and male managers' conflict resolution effectiveness. $(\mathrm{t}(209)=15.66 ; \mathrm{P}<0.05)$. This vividly reveals the influence of gender on conflict resolution effectiveness. The result does not support or confirm hypothesis three.

Ho4: There is no difference between conflict resolution effectiveness of experienced and less experienced managers.

Table 4 reveals that a significant difference exists between experienced and less experienced managers' conflict resolution effectiveness $(\mathrm{t}(209)=7.11 ; \mathrm{P}<0.05)$. The finding indicates that experienced managers were found to be more effective in managing industrial conflict than the less experienced managers. The result does not support or confirm hypothesis four.

\section{Discussion of Findings}

Hypothesis one predicted that there is no relationship between management style and conflict resolution effectiveness among the managers. The finding revealed that a significant relationship exists between management style and conflict resolution effectiveness. The finding shows that the managers in selected work organisations in South-Western Nigeria often utilized participatory management style such as collective bargaining strategy in the course of managing industrial conflict which has often resulted in industrial peace and harmony. The finding of the study corroborates Okedara (1999), Omole (2004), Akintayo, (2004), Korabic, Baril and Watson (1993) and Monroe, Disalvo, Lewis and Berzi (1991) who reported that collective bargaining strategy has been found to be very effective in resolving industrial conflict.The authors stressed further that communication structures during collective bargaining often facilitate freedom of expression and participation of workers in decision making process. The finding of the study implies that industrial conflict tends to be amicably resolved without resulting to strike action in work organisation, when the deliberation and negotiation process on issues relating to employment relations are democratised.

Hypothesis two predicted that there is no difference between male and female managers' conflict management style. The finding reveals that there was no significant difference between male and female managers' conflict management style. The finding indicates that both male and female managers in selected work organisations in South-Western Nigeria equally adopted collective bargaining as effective mechanism for conflict resolution effectiveness.The finding 
corroborates Berryman-Fink and Brunner (1997), Monroe, Disalvo, Lewis and Berzi (1991), Armstrong (2002) and Cleaner (2004) who noted that male and female managers preferred the utilization of collective bargaining as strategy for effective conflict management in work organization. The authors finding in another way round disagreed with the present finding as they argue that female managers tend to use interpersonal, compromising, co-operative, collaborative, avoiding, pro-social, and communicative approaches in the course of managing industrial conflict. While male managers often utilized more aggressive, competitive, confronting, assertive, pro-task and coercive approaches more often than the female managers, even when collective bargaining strategy is being adopted (Gibbs and Lach, 1994; Lay, 1994; Akintayo, 2004; Ajaja, 2004; Adeyemo, 2005).

Hypothesis three predicted that there is no difference between male and female managers' conflict resolution effectiveness. The finding shows that female managers in selected work organisations in South-Western Nigeria were more effective in managing industrial conflict than the male managers. The finding indicates that female manager's adoption of democratic management style in the course of managing industrial conflict which placed them on effectiveness scale level above the male managers, who tend to adopt autocratic management style.The findings corroborates Mobarak (2004), Sallick (2003) and Limond (2002) who submit that male aggressiveness and coercion during collective bargaining process usually make them ineffective in managing industrial conflict. Juliet (2003) and Clement (2004) also support the finding of the study.They contend that female relational and compromising skill acquired through family role tends to afford them opportunity to negotiate and lobby for peaceful co-existence of the organisation rather than male managers that seem to be too coercive and aggressive at the bargaining table.

Hypothesis four predicted that there is no difference between the experienced and less experienced managers conflict resolution effectiveness. The finding reveals that the experienced managers in selected work organisations in South-Western Nigeria are more effective in knowledge. Also, the interpersonal relations skills acquired by the managers tend to influence their adaptation to conflict situation and virtually assist them in handling industrial conflict without resulting to strike action. The finding of the study corroborates Sallick (2003), Juliet (2003), Omole (2004) and Mobarak (2004) who contend that effective management of industrial conflict require accumulated experiences of the managers. The finding implies that the experienced managers tend to be more effective in fostering industrial peace and harmony through their effectiveness in managing industrial conflict.

\section{Conclusion}

The findings of the study established that a significant relationship exists between management style and conflict resolution effectiveness in selected work organisations in South-Western Nigeria.The findings further confirmed that gender and experience are moderating forces in the course of managing industrial conflict. However, the authors argue that industrial conflict can be effectively managed without resulting to strike action, when participatory management style is employed to embrace persuasion, lobbying, effective communication style and compromise. This will definitely foster sustainable industrial peace and harmony since participatory approach to management of conflict is subsumed in collective bargaining process.

\section{Recommendations}

Based on the findings of the study, it is recommended that collective bargaining strategy should be encouraged as conflict resolution strategy in order to guarantee effective management of industrial conflict and sustainable peace and harmony. Also, democratic management style should be encouraged as conflict resolution strategy in order to guarantee effective management of industrial conflict. Both male and female managers should avoid the use of autocratic management style in the course of managing industrial conflict. Rather, participatory management style should be employed during collective bargaining process in order to foster effective management of conflict in work organisations.

More so, female managers should be more empowered to hold managerial position without any gender bias or prejudice. This will allow them to contribute their own quota towards organisational growth and development. This will also afford the female managers the opportunity to utilize their relational skills acquired through home work management in the course of managing industrial conflict. Besides, continuing education programmes should be organised on continuous basis for the managers in order to update their skills and knowledge on stress and conflict management strategies. This could be done by organising on - the - job and off - the - job training programmes that focus on stress, burnout, and administration of incentives at workplace and management of industrial conflict.This will assist in the reduction of industrial action and foster increased productivity at the workplace in Nigeria. Finally, mentoring of the workers through the experienced managers should be encouraged at the workplace in order to foster their effective learning of strategies for managing work-induced stress, burnout and conflict that can affect organisational productivity.To this effect, experienced managers should be retained for human resource development programmes on interpersonal problem-solving training, skill utilisation and conflict resolution in workplaces in Nigeria. 


\section{References}

Adekunle, T. M. (2004). Deregulation of collective bargaining process and conflict management in work organisation in Oyo State. Unpublished M.Ed. Project, University of Ibadan, Ibadan.

Ajaja, A. A. (2004). Gender factors in managerial competence and leadership effectiveness in work organisations in Oyo State. Unpublished Ph.D. Thesis, University of Ibadan, Ibadan.

Akintayo, D. I. (2006). Interpersonal problem solving training, skill utilisation and conflict resolution effectiveness among industrial workers in South -Western Nigeria. Nigerian Journal of Applied Psychology, 8 (2), 76-83

Akintayo, M. O. (2004). Collective bargaining, industrial democracy and conflict management effectiveness in private sector: Nigerian experience. Journal of Labour Studies, 4(1), 10 - 21.

Babajide, E.O. (2000). Comparative analysis of the leadership styles of male and female managers in the banking industry in south western Nigeria. Nigerian Journal of Industrial Relations, 7\&8, 62-70

Berryman - Fink, C. \& Brunner, C. (1997). The effects of sex of source and target on interpersonal conflict management styles. The Southern Speech Communication Journal, 53, 38 - 48.

Cleaner, L. A. (2004). Conflict resolution style and psychological construct intervention at workplace. Journal of Applied Psychology, 48, $216-223$.

Cole K.T. \& Streeter, H.L. (2003). Managing industrial conflict for results. New York: Harper and Row.

Conrad, C. (1991). Communication in conflict: Style - strategy relationships. Communication Monographs, 58,135 - 151. doi:10.1080/03637759109376219, http://dx.doi.org/10.1080/03637759109376219

Duane, M. (1999). Sex differences in styles of conflict management. Psychological Reports, 65, 1033 - 1034.

Faniran, J. O. (2002). Bilateral bargaining and conflict management in state-owned universities in South-Western Nigeria. Unpublished Ph.D. Thesis, University of Ibadan, Ibadan.

Gibbs, P. \& Lach, D. (1994). Gender and workplace dispute resolution: A conceptual and theoretical model. Law and Society Review, 28, 265 - 297. doi:10.2307/3054147, http://dx.doi.org/10.2307/3054147

Juliet, M. T. (2003). Gender difference in conflict management at workplace. Journal of Gender Studies, 9(2), 41 - 48.

Lamude, K. \& Torres, P. (2000). Supervisors' tactics of influence and subordinates' tolerance for disagreement.

Psychological Reports, 87, 1050 - 1050. doi:10.2466/PR0.87.7.1050-1052,

http://dx.doi.org/10.2466/PR0.87.7.1050-1052

Lay, M. (1994). The value of gender studies to professional communication research. Journal of Business and Technical Communication, 8, 58 - 91. doi:10.1177/1050651994008001003, http://dx.doi.org/10.1177/1050651994008001003

Leah, B. S. (2005). Conflict resolution style and experience in management: Moderating effects of gender. Management Communication Quarterly, 12(2), 212 - 220.

Limond, K. M. (2002). Organisational behaviour: Theory and Practice. New York: Macmillan Publishers.

Monroe, C., Disalvo, V., Lewis, J. \& Barzi, M. (1991). Conflict behaviours of difficult subordinates' interactive effects of gender. Southern Communication Journal, 56, 12-21.

Mulac, A. Siebold, D. \& Farris, J. (2000). Female and male managers and professionals criticism giving differences in language use and effects. Journal of Language and Social Psychology, 19, 389 - 416. doi:10.1177/0261927X00019004001, http://dx.doi.org/10.1177/0261927X00019004001

Omole, M. A. L. (2004). Decentralisation of decision making process and perceived workers productivity in work organisations. Journal of Management Studies, 6(2), 46 - 53.

Onyeonoru,I.P.(2005). Industrial sociology: an African perspective. Ibadan: Samlad Printers

Sallick, W. G. (2003). Management effectiveness in conflict situation: Impact of gender and qualification.

Sorenson, P. \& Hawkins, K. (1995). Gender, psychological type and conflict style preference. Management Communication Quarterly, 9, 115 - 127. doi:10.1177/0893318995009001005,

http://dx.doi.org/10.1177/0893318995009001005 
Table 1. Pearson Correlation Table of Analysis on Management Style and Conflict Resolution Effectiveness.

\begin{tabular}{|l|c|c|c|c|c|c|}
\hline \multicolumn{1}{|c|}{ Variable } & $\mathrm{N}$ & Mean & $\mathrm{SD}$ & $\mathrm{r}$ & $\mathrm{P}$ & Remark \\
\cline { 1 - 7 } Management Style & & 14.65 & 10.31 & & & Significant \\
\cline { 1 - 1 } Conflict Resolution Effectiveness. & \multirow{2}{*}{211} & 16.33 & 11.29 & 0.356 & .000 & $(\mathrm{P}<0.05)$ \\
\cline { 3 - 6 } & & & & & & \\
\hline
\end{tabular}

Table 2. Summary of t-test Analysis on Male and Female Managers' Conflict Management Style.

\begin{tabular}{|c|c|c|c|c|c|c|c|}
\hline Variables & $\mathrm{N}$ & Mean & $\mathrm{SD}$ & $\mathrm{df}$ & $\mathrm{t}$ & $\mathrm{P}$ & Remark \\
\cline { 1 - 3 } Male & 123 & 48.43 & 11.39 & & & & Not Significant \\
\cline { 1 - 3 } Female & 88 & 48.76 & 10.16 & 209 & 17.56 & .411 & $(\mathrm{P}>0.05)$ \\
\hline
\end{tabular}

Table 3. Summary of t-test Analysis on Female and Male Managers' Conflict Resolution Effectiveness.

\begin{tabular}{|c|c|c|c|c|c|c|c|}
\hline Variables & $\mathrm{N}$ & Mean & $\mathrm{SD}$ & $\mathrm{Df}$ & $\mathrm{t}$ & $\mathrm{P}$ & Remark \\
\hline Male & 123 & 36.57 & 12.46 & & & & Significant \\
\cline { 1 - 3 } Female & 88 & 37.27 & 13.87 & 209 & 15.66 & .000 & $(\mathrm{P}<0.05)$ \\
\hline
\end{tabular}

Table 4. Summary of t-test Analysis on Conflict Resolution Effectiveness of Experienced and Less Experienced Managers.

\begin{tabular}{|l|c|c|c|c|c|c|c|}
\hline \multicolumn{1}{|c|}{ Variables } & $\mathrm{N}$ & Mean & $\mathrm{SD}$ & $\mathrm{df}$ & $\mathrm{t}$ & $\mathrm{P}$ & Remark \\
\hline Experienced managers & 104 & 60.77 & 16.71 & & & & Significant \\
\cline { 1 - 4 } Less experienced managers & 97 & 61.45 & 15.78 & 209 & 7.11 & .000 & $(\mathrm{P}<0.05)$ \\
\hline
\end{tabular}

